\title{
THE ELECTROENCEPHALOGRAM IN METASTATIC BRAIN TUMORS
}

\author{
P. Pinto Pupo * \\ Rosa Helena Longo ***
}

\author{
A. Mattos Pimenta ** \\ A. Alves ***
}

The early diagnosis of metastatic brain tumor is of special importance in the orientation of surgical therapy, both as regards the primary tumor and the neurosurgical field, and sometimes is a very difficult problem. Therefore the search for new methods towards establishing the basis for an early diagnosis is of fundamental interest.

In the present study it is attempted to answer the following propositions: (a) in the case of a patient with a neoplasm does the normal or the abnormal EEG indicate the absence or the presence of metastasis? (b) does the type of abnormality of the EEG in these cases appear with a frequency which justifies attributing a diagnostic significance to it ? (c) does the topografhy of the focal abnormalities in the EEG coincide with the location of the metastasis as established through surgical, radiologic or clinical procedures?

Papers with appreciable casuistics and focusing directly on the problem of metastatic brain tumors are relatively few: Greenstein and Strauss (1945), 8 cases; Hoefer et al. (1946), 37 cases; Cuneo et al., 7 cases; Gastaut et al. (1954), 16 cases; Torres et al. (1955), 28 cases; Van der Drift et al. (1957 and 1961)), 87 cases; Klass et al. (1958), 42 cases; White et al. (1959)), 15 cases; Strang and Ajmone Marsan (1961), 93 cases; Bagchi and Kooi (1961), 31 cases; Fischer-Williams et al. (1962), 31 cases; Ellingson and Lundy (1962), 27 cases.

The investigators state that the electroencephalographic test is of particular importance in the diagnosis of these tumors 16, $21,39,1,14,12$. They also point out that a normal EEG in cases of brain metastasis is an exception. The EEG signs most frequently found were slo' $\mathrm{w}$ and high voltage delta waves $17,21,33,14,12$. If the tumor is over $2 \mathrm{~cm}$ diameter it can be localized with appreciable precision 16, 36, 21,33,1. The location of the tumor is in itself also a factor in the topographic diagnosis, the frontal and temporal tumors being much more easily located than the parietoccipital ones ${ }^{11}$. The tumors of the posterior possa offer greater difficulty for correct localization. Multiple metastasis are also considered difficult to be recognized as such ${ }^{36,21,1,8}$. Some authors emphasize the fact that the existence of abnormalities in the brain of a patient with carcinoma does not necessarily mean that he has a cerebral

Paper read at the meeting of the Brasilian Society of Neurosurgery, held in Belo Horizonte, in July 1964.

From the Department of Neurology and Neurosurgery of Escola Paulista de Medicina (Prof. Paulino W. Longo): * Associate Professor of Neurology; ** Associate Professor of Neurosurgery; *** Assistants. 
metastasis. The differential diagnosis in relation to alterations induced by other patholcgical conditions of the brain, particularly those of ischaemic nature, must be considered $36,39,1^{12}$.

\section{MATERIAL AND METHOD}

Sixty cases are reported. The diagnosis was confirmed in 28 by surgery, in 26 by clinical examination, arteriography and/or pneumoencephalography, and in 6 by combined clinical and other subsidiary tests. The age of the patients ranged from 35 to 76 years.

The electroencephalographic tracing was done with a Grass instrument, 8 channels, 17 electrodes being placed as routine, with additional ones when necessary, in monopolar recording (common reference ear or vertex, routinely) and successive bipolar recordings, the latter being preferred. Details of the EEG criteria for diagnosis of the lesion and its location will be omited as they are well established in the literature on the subject.

All the tracings were obtained a few days before the clinical diagnosis of the tumor and the surgery, except in 4 cases which will be referred later on in the alscussion of the results.

\section{RESULTS AND COMMENTS}

The cases were divided in large groups according to location of the tumors. They are entered separately in tables 1 to 5 .

The EEG signs considered in the first place were those which indicate marked disturbance of the nervous parenchyma (slow waves), divided in two subgroups, delta waves $(1-3 \mathrm{c} / \mathrm{s})$ and theta waves $(4-7 \mathrm{c} / \mathrm{s})$, those showing a depression of the background electric brain rhythm, and these indicating an irritative factor (sharp waves). They were classified according to their focal or diffuse projection. In addition, the EEG signs indicating a distant lesion (rhythmic delta waves) or involvement of deep structures (rhythmic theta waves) were analysed. The tables depict also the characteristics of background brain rhythm in the areas not involved, regarding organisation and regularity.

The problable location of the tumor as indicated by the EEG entered at the bottom of each table was given at the time of its recording, i. e., before the results of contrast radiological examinations or surgery were known.

Frontal tumors (table 1) - Delta waves $(1-3 \mathrm{c} / \mathrm{s}$ ) were found in 6 and theta waves $(4-7 \mathrm{c} / \mathrm{s})$ in 2 of the surgical cases, and in 3 and 1 , respectively, of the 4 cases with clinical and radiologic diagnosis, and in all cases with clinical exclusively ( 3 patients). Only in 5 cases there appeared at the same time diffuse delta waves in one hemisphere. No signs of involvement of the depth structures of the brain were found in this group. The electrical brain activity in the areas not affected by the tumor appeared well organized in 12 and just fair in 3 of the 15 patients under consideration. These results may be interpreted as indicating intense suffering of the nervous parenchyma, more so in frontal areas. The areas not involved by the tumor, particularly those of the opposite hemisphere, were well preserved. There were no sharp waves. 


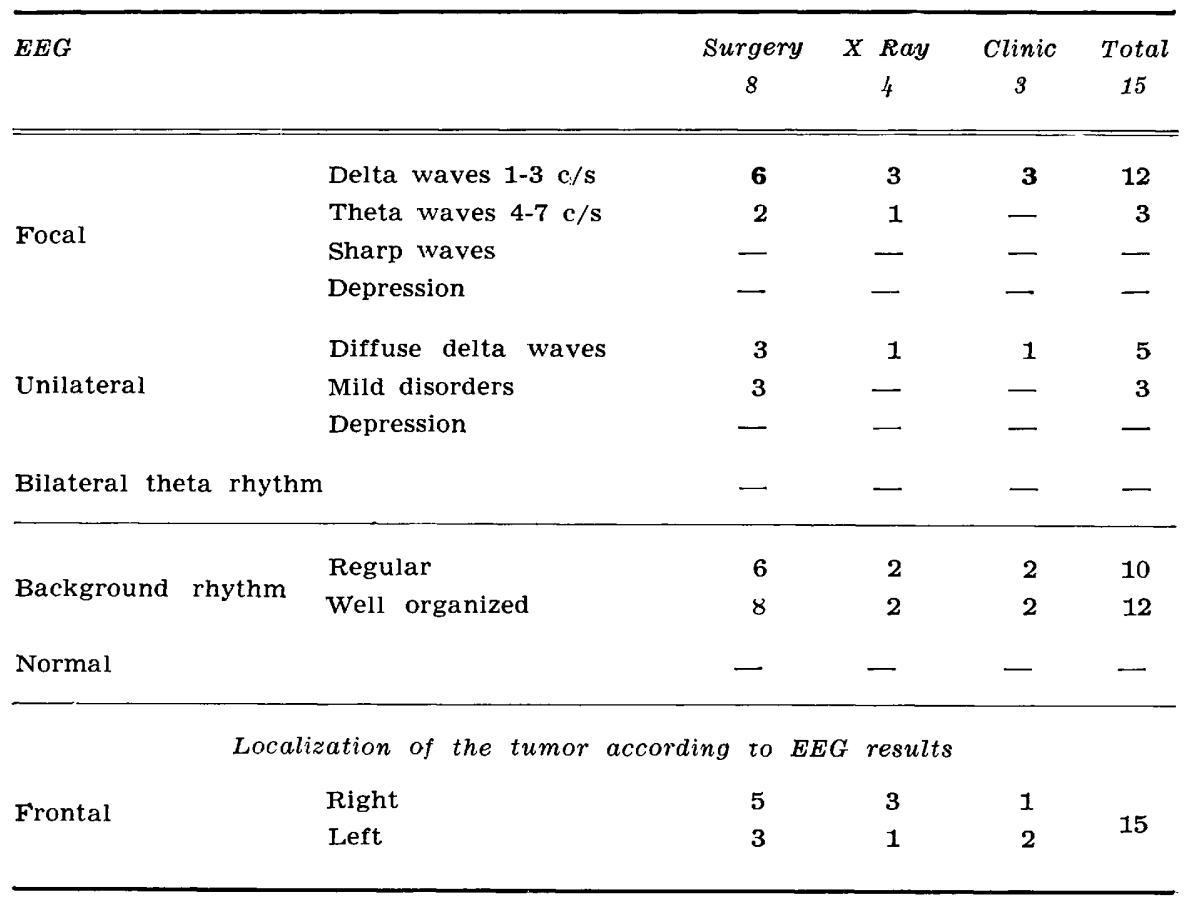

Table 1 - EEG results in 15 cases of frontal metastatic tumors.

As to the location, it was correct in the 8 operated cases, in 4 cases diagnosed by X-rays (arteriography and or pneumoencephalography) and in 2 out of the 3 suspected clinically. In one of the latter the EEG showed delta waves, projecting to the left frontal and prefrontal areas, with some extension to the opposite side, which led us to diagnose a subcortical or basal tumor on the left side. The clinical diagnosis was a right frontal tumor (slight left hemiparesia, bilateral papilledema).

Fronto-parietal tumors (Table 2) - Focal delta waves were found in 3 patients, theta waves in 2 and diffuse delta waves in 7 . Sharp waves appear in 3 and depression of background activity in 2 . The electrical brain activity in the nonaffected areas was normal in only 6 patients. The EEG was normal in 1. This patient had clinical symptoms suggesting metastatic tumor. Yet, the arteriography was normal and pneumoencephalography nonconclusive. Ventriculography, however, showed a slight lowering of the left lateral ventricle. During surgery a small sized metastatic tumor was found. Summarizing, signs of involvement of the nervous parenchyma were again predominant, more diffuse in this group, in accordance with the topography of the metastasis, which was likewise more diffuse.

The topographic diagnosis showed frontal location in 4, fronto-parietal. in 2 , and only the affected hemisphere in 4 patients. 


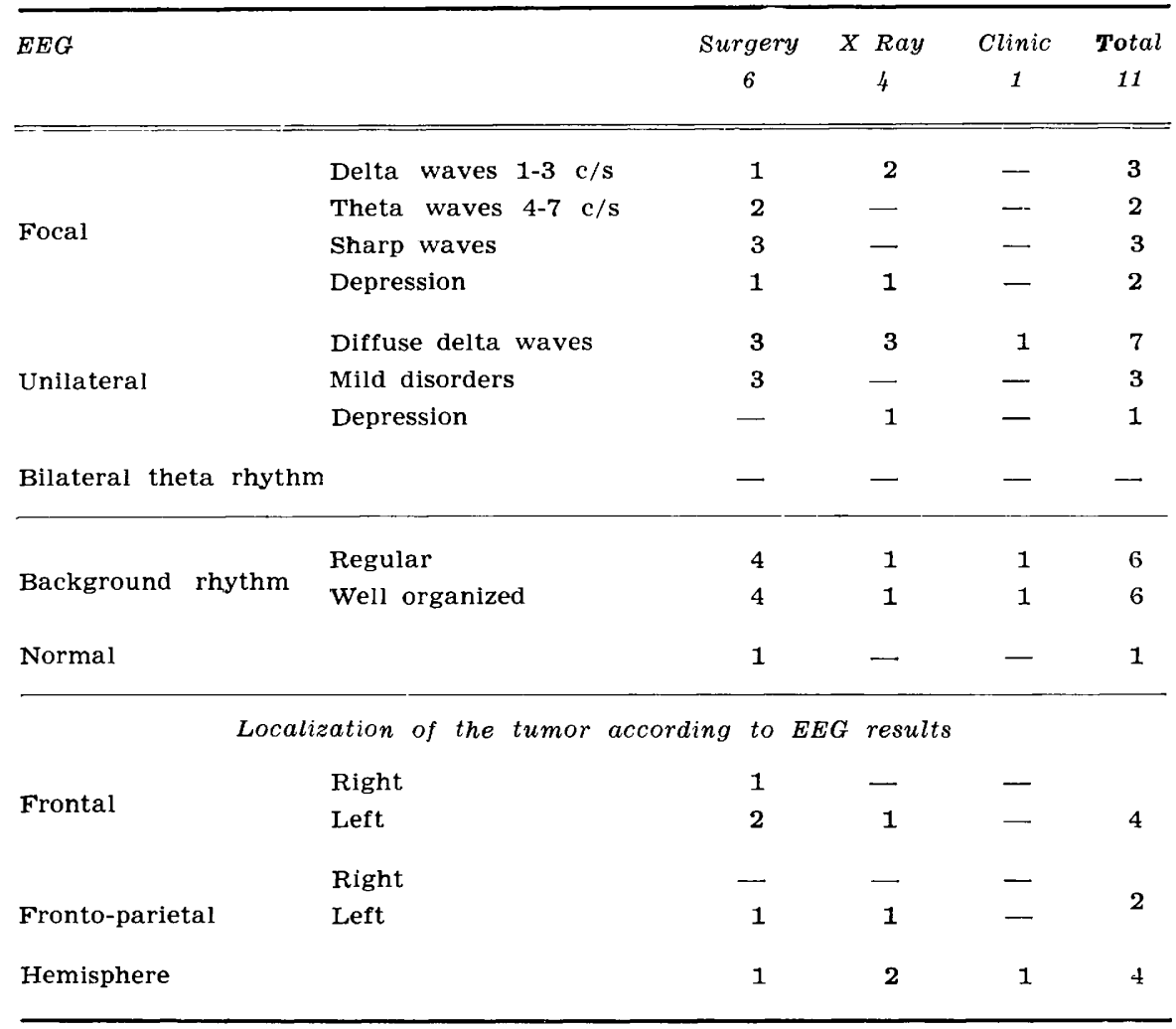

Table 2 - EEG results in 11 cases of fronto-parietal metastatic tumors.

Parietal, parieto-occipital and occipital tumors (Table 3) - The alterations in the parietal tumors are more heterogeneous. Signs of involvement of the nervous parenchyma are predominant, and appeared focally in 6 cases and diffusely in 3 . In 1 case there was also diffuse bilateral theta rhythm. The EEG was normal in 1 case. In that patient the EEG record was done two months before the clinical and operative diagnosis. The metastasis was then probably very small, showing no clinical and electrographic signs. In 2 patients only mild disturbances of the EEG occurred.

As regards the topographic diagnosis, the EEG indicated the parietal lobe in 1, parieto-occipital in 1, involvement of fronto-temporal areas in 2, and fronto-central location with probable involvement of brain stem structures in 1 . In 5 cases only the hemisphere was located, but in 2 the diffuse alterations were distinctly predominant in fronto-temporal areas.

As to parieto-occipital tumors, only one patient (afirmed by surgery) was found with signs of diffuse suffering in the whole hemisphere.

In 3 occipital tumors, also operated upon, the EEG showed signs of intense involvement of the nervous parenchyma of the whole hemisphere in 2 . In 1 


\begin{tabular}{|c|c|c|c|c|c|}
\hline \multirow{3}{*}{$E E G$} & & \multicolumn{2}{|c|}{ Parietal } & \multirow{3}{*}{$\begin{array}{c}\text { Parieto-occipital } \\
\text { Surgery } \\
1\end{array}$} & \multirow{3}{*}{$\begin{array}{c}\text { Occipital } \\
\text { Surgery } \\
3\end{array}$} \\
\hline & & Surgery & $X R a y$ & & \\
\hline & & 5 & 5 & & \\
\hline \multirow{4}{*}{ Focal } & Delta waves $1-3 \mathrm{c} / \mathrm{s}$ & 2 & 4 & 一 & 2 \\
\hline & Theta waves $4-7 \mathrm{c} / \mathrm{s}$ & - & 1 & 一 & 1 \\
\hline & Sharp waves & - & 2 & - & 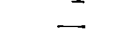 \\
\hline & Depression & - & - & - & 一 \\
\hline \multirow{3}{*}{ Unilateral } & Diffuse delta waves & - & 3 & 1 & 2 \\
\hline & Mild disorders & 1 & 1 & 1 & - \\
\hline & Depression & 1 & 一 & $\rightarrow$ & 1 \\
\hline Bilateral theta rhythm & & - & 1 & 1 & 一 \\
\hline \multirow{2}{*}{ Background rhythm } & Regular & 4 & 1 & 1 & 2 \\
\hline & Well organized & 4 & 3 & 1 & 2 \\
\hline \multirow[t]{2}{*}{ Normal } & & 1 & - & - & 一 \\
\hline & Localization of the & rding to & results & & \\
\hline \multirow{2}{*}{ Parietal } & Right & - & - & - & - \\
\hline & Left & 1 & - & 一 & - \\
\hline \multirow{2}{*}{ Parieto-occipital } & Right & - & - & 一 & 一 \\
\hline & Left & 1 & - & $\longrightarrow$ & 一 \\
\hline \multirow{2}{*}{ Hemisphere } & Right & - & 2 & 1 & 3 \\
\hline & Left & 2 & 1 & 二 & - \\
\hline Deep fronto-central & & - & 1 & & $\longrightarrow$ \\
\hline \multirow{2}{*}{ Fronto-temporal } & Right & - & 1 & $一$ & - \\
\hline & Left & - & 1 & 一 & - \\
\hline
\end{tabular}

Table $3-E E G$ results in 15 cases of parietal, parieto-occipital, and occipital metastatic tumors. 
case the signs of nervous involvement were very. slight, but the clinical diagnosis and the surgery were done 6 months after the EEG. This time interval might explain the discordance between the mild electroencephalographic signs and the actual tumor as disclosed through surgery.

Temporal tumors (Table 4) - Focally projected delta waves appeared in only 3 cases, while diffuse alterations appeared in 5 . In 1 patient there were signs of involvement of the mesodiencephalic structures. In 3 patients there appeared focal sharp waves, unilateral in 2 in accordance with the tumor, and bilateral in 1 (in which the affected hemisphere was diagnosed). A greater extension of the involvement of the nervous parenchyma (such as recognized for temporal tumors generally) is clear. In 3 cases only the affected hemisphere was located; in 1 fronto-temporal areas were involved and in 1 distinct signs of depth invasion of the nervous parenchyma. In only 3 out of 8 patients, a pure temporal lesion was located. Nevertheless, 1 of these cases, in which the tumor had been diagnosed on the left side by delta waves, when the pneumoencephalogram and the carotid arteriogram were normal, was operated upon for right temporal metastasis seven months after. The time elapsed perfectly explains the nonexistence of EEGraphic alterations on the right hemisphere, site of the operated tumor. On the left side, there were no radiologic or clinical evidences of the tumor at the time when the EEG showed alterations. In the other case, while distinct sharp waves suggested a right hemisphere location, a temporal tumor on the left side, was found. No clear explanation for this finding can be invoked. The possibility should not be discarded that the EEG disturbances in the opposite hemisphere are induced by another minute metastasis. In the third case the EEG correctly located the tumor by delta waves and depression of the rhythm.

In 1 patient with temporo-parietal tumor the EEG showed temporal sharp waves and signs of involvement of the mesodiencephalic brain structures.

In 1 patient with operated temporo-frontal tumor, the EEG indicated signs of involvement of the nervous parenchyma (delta waves) in temporofrontal areas plus feeble signs of diffuse suffering in the whole hemisphere.

Posterior fossa tumors (Table 5) - In patients with metastatic cerebellar tumors the EEG showed signs of probable involvement of mesodiencephalic structures in 4 cases (endocranial hypertension); it was entirely normal in 3 and in 1, which was on the whole normal, it showed sharp waves in posterior temporal areas on the right side. It should be noted that the EEG was done 6 months previously to the clinical diagnosis and surgery. In the only case with a brain stem tumor the EEG also showed signs of median-depth involvement.

Significant EEG results - The EEG showed significant alterations in 49 cut of 51 patients with metastatic tumors in the brain hemispheres. In only 2 cases the EEG was normal. In one of these the EEG examination was done 6 months before the clinical and neurosurgical diagnosis of the tumor, which certainly explains the negative result. In the other one, the small size of the tumor could be the explanation. 


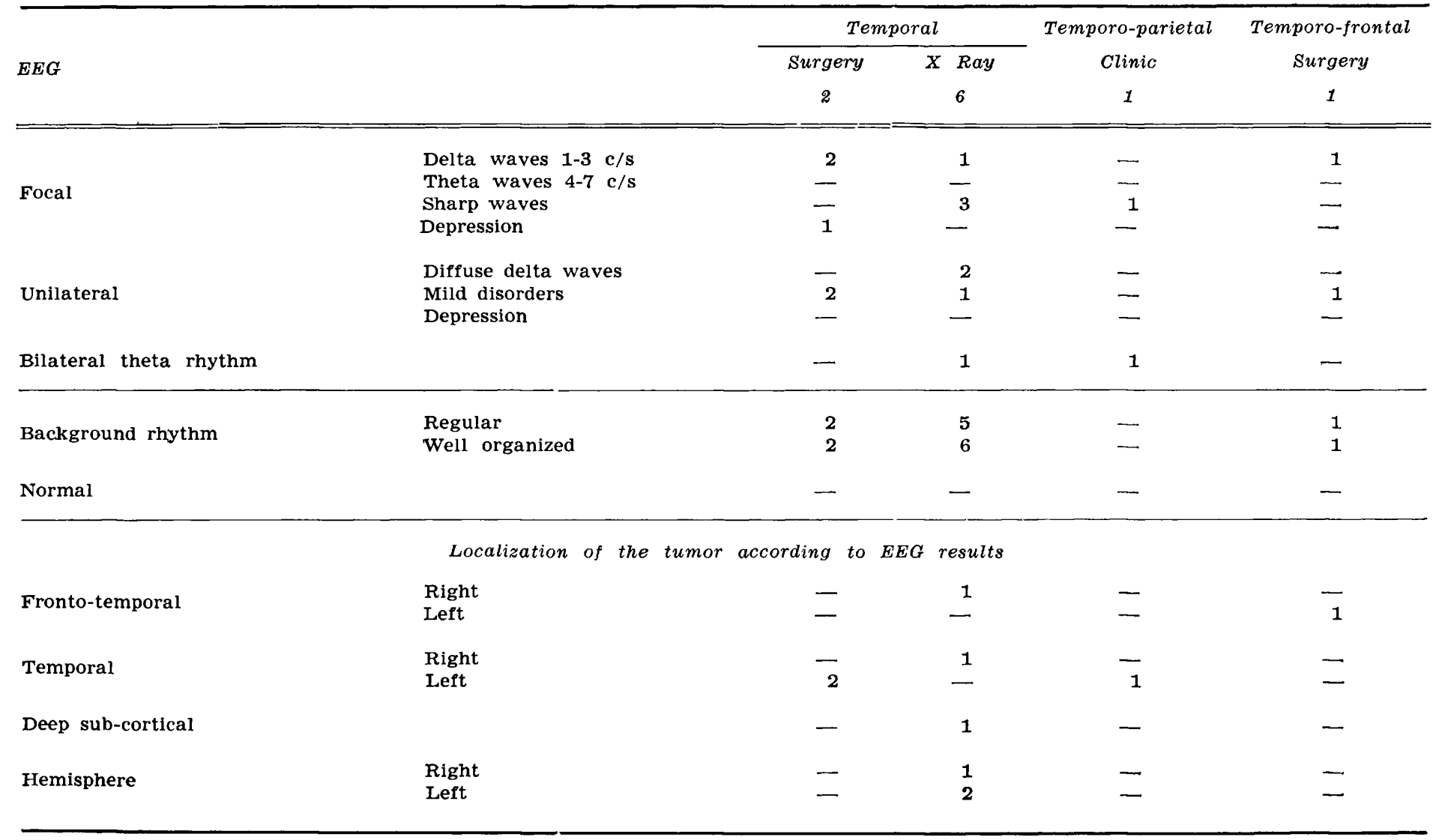

Table $4-E E G$ results in 10 cases of temporal, temporo-parietal, and temporo-frontal metastatic tumors. 


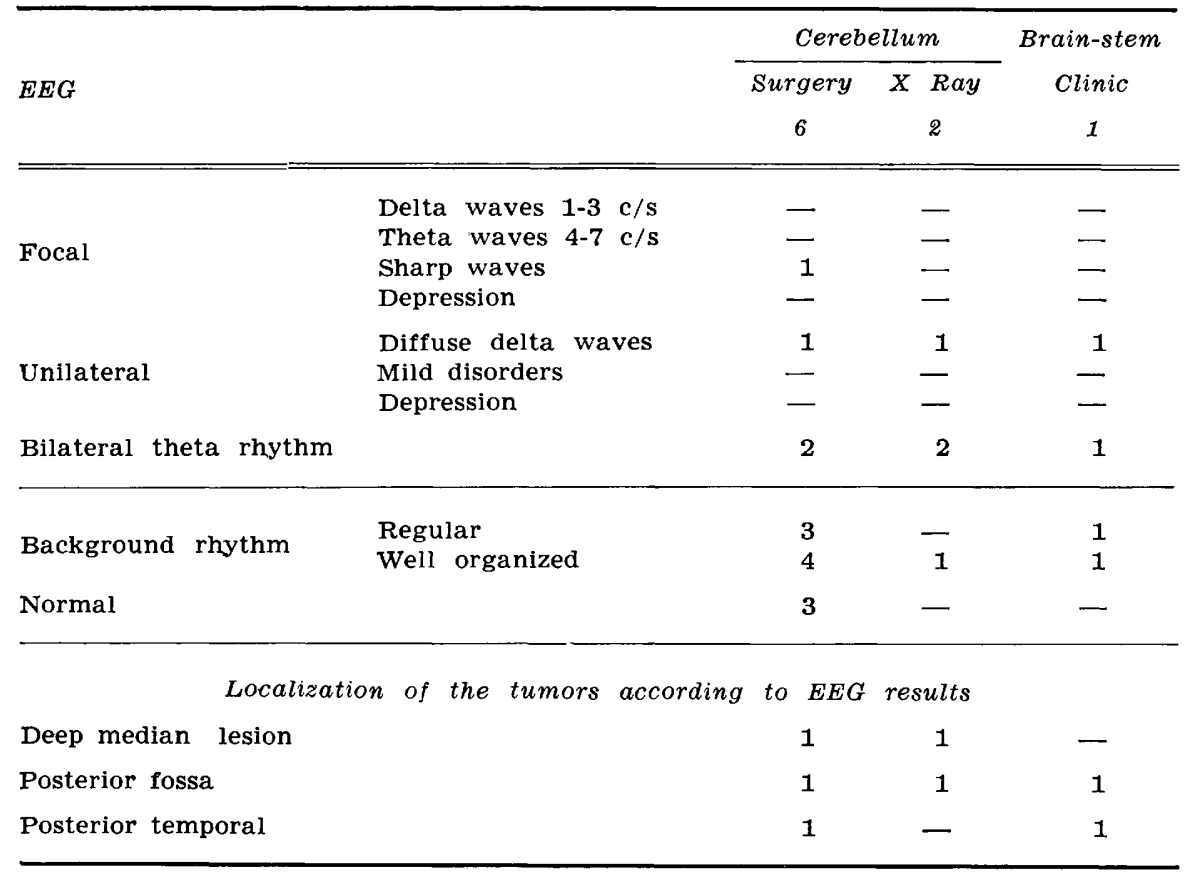

Table $5-E^{\prime} E^{\prime} G$ results in 9 cases of cerebellar and brain-stem metastatic tumors.

The type of abnormality shown in the EEG was predominantly the uccurrence of high voltage delta waves (1-3 c/s.), meaning acute suffering of the nervous parenchyma in the areas near the tumor. The delta waves were mainly focal in the tumors of the frontal lobe and more diffuse in those of the temporal or parietal regions, or in the tumors which were also diffuse (temporo-parietal and fronto-parietal). The sharp waves indicating and irritant factor of the nervous parenchyma, were much more frequent in the neighborhood of the temporal areas ( 7 out 9 patients). Depression of the basal rhythm was also rarely found. The signs of involvement of the mesodiencephalic structures (bilateral theta rhythm) appeared only seldom in tumors of the brain hemisphere, and mainly in temporal or parietal, not in frontal or occipital tumors.

As to the posterior fossa tumors (9 cases), the EEG showed signs of involvement of the mesodiencephalic structures in 5; in 3 of these there were concomitantly diffuse, non-persistent delta waves in both cerebral hemispheres which led to a suspicion of a posterior fossa process. In 3 other cases the tracing was normal. In 1 case the findings of sharp waves in posterior temporal areas could not be related to the tumor.

As far as location was concerned the EEG results were sensibly more concordant in the cases of frontal tumors. The majority of cases of temporal tumors presented diffuse signs of lesions in the depth of the hemispheres. 
However, considering that our material consisted of metastatic tumors, under clinico-radiologic and surgical observation, we coud never try to establish a strict topographic correlation, as these tumors in many patients are multiple and also provoke intense reactions in the surrounding nervous parenchyma, which causes the lesion to extend beyond the actual tumor.

\section{SUMMARY AND CONCLUSIONS}

Sixty cases of intracranial metastatic tumors diagnosed either clinically or by neurosurgery ( 28 operative cases, 26 with radiological contrast examinations and 6 with clinical diagnosis only) are reported. The EEG tests had been made previously to the diagnosis of metastasis.

The EEG results are analysed according to the previous impression gained from this test and are presented in 5 tables, on which the cases are dividcd as per the brain topography of the metastasis. The positive EEG data are analysed and the possibility of topographic diagnosis discussed. The result; agree with those presented in the literature. The AA. reach the following conclusions: 1) in patients with suspect brain metastasis the normal EEG allows with great probability to exclude the possibility; 2) in patients with malignant tumor the EEG signs of involvement of the nervous parenchyma are the most important elements for positive diagnosis of brain metastasis; 3 ) in the cases of metastasis developing at the posterior fossa, either there were indicative signs of the process at that level or the EEG was normal; 4) the EEG signs of an irritant process at the brain cortex were less frequent and, in the majority of cases, appeared in the temporal and parietal areas; 5) the signs of involvement of the mesodiencephalic structures in tumors of the brain hemispheres appeared only when the tumor was located in the median part of the hemisphere (temporal or parietal lobes); 6) signs of depression of the basal electric brain activity in the affected areas appeared rarely and in cases of parietal or occipital tumors; 7) the electric brain activity of other areas of the involved hemisphere or in the opposite hemisphere was normal in the majority of the cases observed.

Considering the results of the literature and their own the AA. believe that the EEG could be a semiological method to be used at the preoperative examinations of patients with malignant tumors, 'with a view at establishing the possible existence of brain metastasis even in the absence of clinical symptoms. The evidence is obviously most important for orientation of the therapy in such cases, whether surgical or not.

\section{RESUMO E CONCLUSÓES}

\section{O eletrencefalograma nos tumores metastáticos do encéfalo}

São apresentados 60 casos de tumores metastáticos intracranianos, diagnosticadcs clìnicamente ou pela neurocirurgia (28 casos operados, 26 com exames radiológicos contrastados e 6 com diagnóztico clínico). Os exames 
eletrencefalográficos tinham sido feitos prèviamente e na mesma época do diagnóstico e da intervenção.

Os resultados do EEG, interpretados prèviamente ao conhecimento do diagnóstico clínico, são apresentados em 5 quadros, nos quais os casos são catalogados segundo a topografia da metástase. Os dados fornecidos pelo EEG são analisados e a possibilidade do diagnóstico topográfico é discutida. Os resultados são concordantes com os da literatura.

Os AA. concluem: 1) nos pacientes com suspeita de metástase cerebral o EEG normal permite, com grande probabilidade, excluir essa possibilidade; 2) nos pacientes com tumores malignos os sinais eletrencefalagráficos indicando sofrimento do parênquima nervoso são os mais importantes para um diagnóstico afirmativo de metástase cerebral; 3) nos casos de metástases desenvolvendo-se na fossa posterior o EEG se mostra normal ou, então, revela sinais indicativos de processo nessa região; 4) os sinais eletrencefalográficos de processo irritativo no córtex cerebral foram pouco frequentes e, na maioria dos casos, apareceram nas áreas temporais ou parietais; 5) os sinais de envolvimento das estruturas mesodiencefálicas em tumores dos hemisférios cerebrais aparecem nos casos de localização na parte mediana do hemisfério cerebra] (lobos temporais ou parietais); 6) os sinais de depressão da ativodade elétrica cerebral de base nas áreas afetadas aparecem raramente em casos de tumores parietais ou occipitais; 7) a atividade elétrica cerebral em outras áreas do hemisfério envolvido pelo tumor e nas do hemisfério oposto se apresentou normal na maioria dos casos.

Considerando os resultados da literatura e os seus próprios os AA. pensam que o EEG é um método semiológico que deva ser usado em todos os casos de pacientes com tumores malignos e candidatos a um terapêutica cirúrgica. A evidenciação de uma metástase cerebral, por êste método semiológico, evitará que o paciente seja submetido a intervenção cirúrgica penosa e inútil.

\section{REFERENCES}

1. BAGCHI, B. K: \& KOOI, K. A. - Electroencephalography and brain tumors. The Univ. Mich. Bull, 27:50-60, 1961.

2. BAGCHI, B. K.; KoOI, K. A.; SELviNG, B. T. \& CALHOUN, H. D. - Subtentorial tumors and other lesions: an electroencephalographic study of 121 cases. EEG Clin. Neurophysiol. 13:180-92, 1961.

3. BAGCHI, B. K. \& BASSET, R. C. - Some additional electroencephalographic techniques for the localization of intracranial lesions. J. Neurosurg. 4:348-69, 1947.

4. BOUNES, L. \& DREYFUS-BRISSAC, C. - EEG des tumeurs hémisphériques intra et sous-ventriculaires. Rev. Neurol. 83:613-18, 1950.

5. CASE, Th. \& BUCY, P. - Localization of cerebral lesions by electroencephalography. J. Neurophysiol. 1:425-61, 1938.

6. CASE, Th. - Electroencephalography in the diagnosis and localization of intracranial lesions. J. Nerv. Ment. Dis. 87:598, 1938. 
7. СовB, W. A. - The electroencephalographic localization of intracranial neoplasms. J. Neurol. Neurosurg. Psychiat. 7:96-102, 1944.

8. СОВB, W. A. - The EEG of specific lesion in Electroencephalography. A symposium on its various aspects. Denis Hill and G. Parr, 1963, p. 362.

9. CUNEO, H. M.; RAND, C. W. \& SJAARDEMA, H. - Analysis of electroencephalographic findings in 40 cases of verified brain tumor. Bull. Los Angeles neurol. Soc. 15:22-36, 1950.

10. DALY, D. D. \& THOMAS, J. E. - Sequential alterations in the electroencephalograms of patients with brain tumors. EEG Clin. Neurophysiol. 10:395-404, 1958.

11. DREYFUS-BRISSAC, C.; LAIREY-BOUNES, G. C.; SCARPELEZOS, S. \& FISCHGOLD, H. - Rythmes pathologiques détectés à distance des tumeurs des hémisphères cérébraux. Sem. Hop. Paris 26:2623-28, 1950.

12. ELLINGSON, R. J. \& LUNDY, B. W. - Electroencephalograms of patients suspected of having metastatic lesions of the brain. Cancer 15:1138-41, 1962.

13. FAURE, J.; DROOGLEEVER-FORTUYN, J.; GASTAUT, H.; LARRAMENDI, L.; MARTIN, P.; PASSOUANT, P.; RÉMOND, A.; TITECA, J. \& WALTER, W. G. - De la génèse et de la signification des rythmes recuellis à distance dans les cas de tumeurs cérébrales. EEG Clin. Neurophysiol. 3:429-32, 1951.

14. FISCHER-WILliaMS, M.; LAST, S T.; LYBERI, G. \& NORTHFIELD, W. C. - Clinic EEG study of 128 gliomas and intracranial metastatic tumors. Brain $85: 1-46,1962$.

35. GASTAUT, H. \& TAMELET, J. - Caractères électrographiques directs et indirects des tumeurs hémisphériques sous-corticales. Rev. Neurol. 81:411-16, 1949.

16. GASTAUT, H.; ROGER, A. \& CHATRIAN, J. E. - EEG findings in cases of lung cancer. EEG Clin. Neurophysiol. 6:525, 1954.

17. GREENSTEIN, I. \& STRAUSS, H. - Correlation between electroencephalogram and histological structures of gliogens and metastatic brain tumors. J. Mt. Sinai Hosp 12:874-77, 1945 (citation in Year Book of Neurol. Psychiat. Endocrinol., 1945, p. 85).

18. HESS, R. — Elektroencephalographische Studien bei Hirntumoren. Georg Thieme Verlag, Stuttgart, 1958.

19. HOEFER, P. F. A.; SCHLESINGER, E. B. \& PENNES, H. H. - Clinical and electroencephalographic findings in a large series of verified brain tumors. Tr. Am. Neurol. Ass. 71:52, 1946.

20. JUNG, R. - Die Bedeutung des Elektrencephalograms für die Diagnostik der Hirntumoren. Regensburger Jahrbuch fur arztliche Fortbildung, 1957/58, pp. 1-15.

21. KLASS, D. W. \& BICKFORD, R. G. - The electroencephalogram in metastatic tumors of the brain. Neurology 8:333-37, 1958.

22. KERSHMAN, J.; CONDE, A. \& GIBSON, W. - Electroencephalography in differential diagnosis of supratentorial tumors. Arch. Neurol, Psychiat. 62: $255-68,1949$.

23. LONGO, P. W.; PUPO, P. P.; PIMENTA, A. M. \& LEMMI, O. - Tumor da regiāo do III ventrículo: diagnóstico eletroencefalográfico. Arq. Neuro-Psiquiat. (São Paulo) 6:169-77, 1948. 
24. LONGO, P. W.; PUPO, P. P.; PAZZANESE, O. \& PIMENTA, A. M. - Résultats éléctroencéphalographiques dans 33 cas de tumeurs intracraniennes chirurgicalement verifiées. Arq. Neuro-Psiquiat. (São Paulo) 8:43-46, 1950.

25. MAGNUS, O.; STORM VAN LEEWEN, W. \& COBB, W. - Electroencephalography and cerebral tumors. EEG Clin. Neurophysiol. Supplement n.o 19, 1961.

26. MARTIN, P. \& MARTIN, M. - Signes éléctrographiques des tumeurs de la fosse postérieure. Rev. Neurol. 82:540-46, 1950.

27. PASSOUANT, P.; CADILHAC, J. \& VLAhOVITCH, B. - Rythmes delta bifrontaux et leurs relations avec lésion anatomique mesodiencéphalique. Rev. Neurol. 93:474-77, 1955.

28. PUECH, M. P. \& LERIQUE-KOECHLIN, M. - L'électroencéphalographie dans les abscès du cerveau. Rev. Neurol. 76:303-4, 1944.

29. PUPO, P. P. \& PIMENTA, A. M. - A electroencefalografia nos tumores intracranianos. Arq. Neuro-Psiquiat. (São Paulo) 4:373-390, 1946.

30. PUPO, P. P.; PAZZANESE, O. \& PIMENTA, A. M. - A electroencefalografia nos tumores intracranianos. Arq. Neuro-Psiquiat. (São Paulo) 6:1-24, 1948.

31. PUPO, P. P.; PIMENTA, A. M. \& ZUKERMAN, E. - Estudo electroencefalográfico das afecções cirúrgicas da fossa posterior. Arq. Neuro-Psiquiat. (São Paulo) 12:243-48, 1954

32. SILVERMAN, D. \& GROFF, R. A. - Brain tumor depth determination by electrographic recordings during sleep. Arch. Neurol. Psychiat. 78:15-28, 1957.

33. STRANG, R. \& AJMONE MARSAN, C. - Brain metastasis: pathological and electroencephalographical study. Arch. Neurol. 4:21-32, 1961.

34. STORM VAN LEEWEN, W. - EEG in metastatic brain tumor before, during and after radiation treatment. EEG Clinical Neurophysiol. 2:331-32, 1950.

35. TORRES, F.; NETSKY, M. C. \& ZIEGLER, D. K. - Correlation of electroencephalographic and pathological findings in a series of metastatic brain tumors. Acta Neurol. Latino-Amer. 1:156-66, 1955.

36. VAND DER DRIFT, J. H. A. - The significance of electroencephalography for diagnosis and localisation of cerebral tumors. H. S. Stenfert Krose N. V. Leiden, 1957.

37. VAN DER DRIFT, J. H. A. \& MAGNUS, O. - Cerebral metastasis in EEG and cerebral tumors. EEG Clin. Neurophysiol., Supplement 19, 1961, pp. 138-140.

38. 'WALTER W. G. - The technique and applications of electroencephalography. Lancet 2:305, 1936.

39. WHITE, Ph. T.; TAYLOR, R. \& NELSON,, J. - EEG changes associated with bronchogenic carcinoma with autopsy studies. EEG Clin. Neurophysiol. $11: 842-43,1959$.

Department of Neurology and Neurosurgery - Escola Paulista de Medicina Caixa Postal 5496 - São Paulo, SP — Brasil. 